References:

[1] Jennette JC, Falk RJ, Bacon PA, et al. (2013) 2012 revised International Chapel Hill Consensus Conference Nomenclature of Vasculitides. Arthritis Rheum 65(1), 1-11.

Acknowledgements: This study was supported by a faculty research grant of Yonsei University College of Medicine (6-2016-0145) and by a grant from the Korea Health Technology R\&D Project through the Korea Health Industry Development Institute, funded by the Ministry of Health and Welfare, Republic of Korea (HI14C1324).

Disclosure of Interest: None declared

DOI: 10.1136/annrheumdis-2017-eular.4573

\section{AB0572 EFFICACY AND SAFETY OF RITUXIMAB FOR ANCA ASSOCIATED VASCULITIS}

K. Fujita ${ }^{1}$, M. Hirata ${ }^{1}$, S. Oguni ${ }^{2}$, Y. Nakashima ${ }^{2}$, Y. Nomura ${ }^{2}$, Y. Yamamura ${ }^{3}$, K. Nonaka ${ }^{2}$, N. Shibutou ${ }^{1,2}$, N. Momoki ${ }^{2}$, A. Ueno ${ }^{1}$, T. Ombe ${ }^{2}$, K. Maruyama $^{2}$, M. Hiramatsu ${ }^{2}$, M. Yamamura ${ }^{1} .{ }^{1}$ Centre for Rheumatology; ${ }^{2}$ Centre for Kidney Diseases, Okayama Saiseikai General Hospital; ${ }^{3}$ Okayama University Hospital, Okayama, Japan

Background: In Japan, rituximab (RTX) has become one of the dominant alternatives for ANCA associated vasculitis (AAV) even for elderly patients.

Objectives: The efficacy and safety of RTX for AAV patients was determined at our hospital.

Methods: Nineteen patients with AAV, including 14 newly diagnosed patients and 6 relapsed patients, had been treated with RTX. There were 10 males and 9 females. They were all MPO-ANCA positive; 16 were diagnosed with microscopic polyangiitis (MPA), 2 with granulomatosis with polyangiitis (GPA), and 1 with undifferentiated, according to the EMA classification of AAV. The mean age at RTX induction was 71.3 years (range: $40-82$ years). The efficacy was evaluated by the BVAS score at the time of first induction and after 6 month treatment. Adverse events were recorded during the 6-month treatment.

Results: The mean of BVAS decreased from 17.3 (range: 7-35) at the first induction to $1.2(0-4)$ at 6 month of RTX treatment. Of the 10 patients who could be followed-up for over 6 months, 7 patients achieved remission (BVAS=0) (remission rate: $70.0 \%$ ). The titer of mean MPO-ANCA decreased $136.1 \mathrm{IU} / \mathrm{mL}$ $(9.9-300 \mathrm{IU} / \mathrm{mL})$ to $44.4 \mathrm{IU} / \mathrm{mL}(1.0-114.0 \mathrm{IU} / \mathrm{mL})$ at 6 month. The dose of prednisolone decreased from $34.4 \mathrm{mg} /$ day $(5-60 \mathrm{mg} /$ day) at baseline to $5.5 \mathrm{mg} /$ day $(0-10 \mathrm{mg} / \mathrm{day})$ at 6 month. The adverse events were as follows: 3 patients experienced reactivation of cytomegalovirus (CMV) with a CMV colitis, one patient with sepsis following urinary-tract infection, and one patient with bacterial pneumonia. One patient with PMA died of exacerbation of the disease itself.

Conclusions: In Japan, AAV, mostly MPO-ANCA-positive PMA, affects elderly persons. The results suggest that RTX may provide a therapeutic option for elderly patients at the age of over 70 years with severe MPA, with an acceptable safety profile and rapid glucocorticoid tapering. However, careful monitoring for infectious diseases will be needed.

Disclosure of Interest: None declared

DOI: 10.1136/annrheumdis-2017-eular.2568

\section{AB0573 AUTOLOGOUS STEM CELL TRANSPLANTATION IN THE MANAGEMENT OF REFRACTORY BEHÇET'S SYNDROME: A CASE SERIES FROM A SINGLE CENTRE OF EXCELLENCE}

L. Chadwick ${ }^{1,2}$, D. Thong ${ }^{2}$, J. Nair ${ }^{1}$, N. Goodson ${ }^{1,2}$, R. Moots ${ }^{1,2} .{ }^{1}$ Aintree University Hospital; ${ }^{2}$ Institute of Ageing and CHRonic Disease, University of Liverpool, Liverpool, United Kingdom

Background: Evidence regarding haematopoietic stem cell transplantation (HSCT) in refractory Behçet's Syndrome (BS) is limited. A systematic review in 2014 identified 20 patients with BS who had undergone HSCT, from which 9 patients underwent HSCT with refractory BS as the primary indication. Of these 20 patients: 15 achieved complete remission, 1 patient achieved partial remission, 2 patients relapsed, 1 patient died and 1 had no outcome reported. Nine patients had reported complications, 5 patients had no complications and 6 patients were missing data. All data was sourced from single case studies (1).

Objectives: Outline the indications, outcomes and complications of HSCT in a case series of 4 patients with BS managed at a single centre of excellence.

Methods: Case notes were reviewed for 4 patients from the Liverpool Behçet's Centre of Excellence (LBCE) who have undergone HSCT.

Results: The primary indication for 3 of the 4 patients who have undergone autologous HSCT at LBCE was refractory BS. Patient 1 underwent HSCT for multiple myeloma, but suffered from severe BS with neurological and venous involvement and is now in partial remission with occasional mild muco-cutaneous ulceration, not requiring systemic immunosuppression. Patient 2 underwent HSCT for severe refractory neuro-Behçet's. This patient is now in complete remission after commencing azathioprine for oral ulceration. The indications for HSCT in patients 3 and 4 were severe muco-cutaneous ulceration and dermatological involvement refractory to numerous biologic agents with high ongoing steroid dependency. Patient 3 also had previous thrombophlebitis and patient 4 had previous gastro-intestinal ulceration. They are both currently in complete remission but follow up time is limited. Patient 3 had a post-HSCT complication of pneumonia and mucositis which resolved without persistent morbidity, patient 4 had an upper limb deep vein thrombosis (DVT) as an inpatient. Conclusions: HSCT is an effective treatment modality for severe refractory BS and can result in medication free remission. However, the associated risks should be considered and alternative treatment options deliberated or exhausted before opting for this treatment modality.

References:

[1] Soysal T, Salihoğlu A, Esatoğlu SN, Gültürk E, Eşkazan AE, Hatemi G, et al. Bone marrow transplantation for Behçet's disease: a case report and systematic review of the literature. Rheumatology. 2014; 53(6):1136-41.

Disclosure of Interest: None declared

DOI: 10.1136/annrheumdis-2017-eular.4745

\section{AB0574 VENOUS INVOLVEMENT IN BEHCET'S DISEASE: A RETROSPECTIVE ANALYSIS OF 75 CASES}

L. Belhadi, A. Hariz, I. Boukhris, I. Kechaou, S. Azzabi, L. Ben Hassine, E. Cherif, N. Khalfallah. Internal medecine B, Charles Nicolle Hospital, Tunis, Tunisia

Objectives: Behcet's disease $(\mathrm{BD})$ is a chronic multisystem inflammatory disease characterized by recurrent mouth and genital ulcerations. The vascular involvement varies from 7,7 to $43 \%$ depending on ethnicity. Venous lesions are

Abstract AB0573 - Table 1

\begin{tabular}{|c|c|c|c|c|c|c|c|c|c|c|}
\hline Patient & $\begin{array}{c}\text { Age } \\
\text { at HSCT } \\
\text { (years) }\end{array}$ & Sex & $\begin{array}{c}\text { Disease } \\
\text { duration at HSCT } \\
\text { (years) }\end{array}$ & $\begin{array}{c}\text { BS } \\
\text { manifestations }\end{array}$ & $\begin{array}{l}\text { Treatment } \\
\text { pre-HSCT }\end{array}$ & $\begin{array}{c}\text { HSCT } \\
\text { Indication }\end{array}$ & $\begin{array}{l}\text { Follow up } \\
\text { (months) }\end{array}$ & Complications & Outcome & $\begin{array}{c}\text { Treatment } \\
\text { post-HSCT }\end{array}$ \\
\hline 1 & 47 & $M$ & 6 & $\begin{array}{l}\text { OU } \\
\text { GU } \\
\text { S } \\
\text { MSK } \\
\text { V } \\
\mathrm{N}\end{array}$ & Tacrolimus & Multiple Myeloma & 135 & Nil & OU GU (minor) & Pred 4mg \\
\hline 2 & 29 & M & 5 & $\begin{array}{c}\text { OU } \\
\text { GU } \\
\text { S } \\
\text { Ocular } \\
\mathrm{N}\end{array}$ & $\begin{array}{c}\text { MMF } \\
\text { Tacrolimus } \\
\text { IFX } \\
\text { ETN } \\
\text { CYCP } \\
\text { ALN }\end{array}$ & Neuro-Behçets & 80 & Nil & 1x flare $2013(\mathrm{OU})$ & AZA \\
\hline 3 & 51 & M & 4 & $\begin{array}{c}\text { OU } \\
\text { GU } \\
\text { S } \\
\text { V } \\
\mathrm{N}\end{array}$ & $\begin{array}{c}\text { AZA } \\
\text { MMF } \\
\text { ETN } \\
\text { ADA } \\
\text { Certolizumab } \\
\text { Interferon }\end{array}$ & Refractory, severe OU \& GU & 1 & DVT & Remission & nil \\
\hline 4 & 42 & $\mathrm{~F}$ & Unknown & $\begin{array}{c}\text { OU } \\
\text { GU } \\
\text { S } \\
\text { MSK } \\
\text { Gastro }\end{array}$ & $\begin{array}{c}\text { AZA } \\
\text { Leflunomide } \\
\text { MTX } \\
\text { Thalidomide } \\
\text { IFX } \\
\text { ADA } \\
\text { ETN } \\
\text { ALN }\end{array}$ & Refractory, severe OU \& GU & 8 & Pneumonia \& Mucositis & Remission & Pred $40 \mathrm{mg}$ \\
\hline
\end{tabular}

$\overline{\mathrm{OU}}=$ oral ulceration, $\mathrm{GU}=$ genital ulceration, $\mathrm{MSK}=$ musculoskeletal, $\mathrm{S}=$ skin, $\mathrm{N}=$ neurological, $\mathrm{V}=$ vascular. $\mathrm{AZA}=$ azathioprine $, \mathrm{CYCP}=\mathrm{cyclophosphamide}, \mathrm{MMF}=\mathrm{mycophenolate}$ motefil, $\mathrm{MTX}=$ methotrexate. ADA = adalimumab, IFX = Infliximab, ETN = Etanercept, ALN = Alentuzumab. 